\title{
A orientação dada pelo CRP-06
}

Transcrevemos aqui, na íntegra, o editorial, A Etica Profissional no Trabalho com Paciente de Aids, publicado no Jornal do CRP-06, $\mathrm{n}^{\circ} 48$, fevereiro/março de 1987.

"O Conselho Regional de Psicologia tem sido procurado, recentemente, para expressar sua posição frente ao atendimento de pacientes de Aids. Nāo sobre qualquer situaçāo relativa a esse atendimento. Mas, especificamente, sobre aquela em que o paciente, comprovadamente aidético, afirma nas sessões terapêuticas que, de forma deliberada, fará a propagação da doença. $O$ que deve fazer o profissional? Garantir acima de tudo o sigilo? Rompê-lo? Denunciar à polícia?

Essas questões ficam acirradamente conflitivas para nós, psicólogos, pelo tipo mesmo de trabalho que desenvolvemos. Não nos atendo sempre às condições objetivas, aos fatos reais, $e$, em geral, lidando com a subjetividade, as fantasias, os fatos psíquicos, somos conduzidos, muitas vezes, a perceber a fala do cliente, no limite entre o desejo de "destruir o mundo', diante da inevitabilidade de sua morte, e a ação concreta de multiplicar parceiros sexuais ou doar sangue em condições precárias de controle, por exemplo. Somos, a partir daí, muitas vezes, conduzidos a, de um lado, analisar e interpretar o desejo e, de outro, colocar-nos diante da urgência de uma atitude nossa que impeça outras atitudes do cliente com conseqüências, previsivelmente, nefastas.

Em meio a isso, a crivo ético da atuação do psicólogo prevê o sigilo do que lhe é dito pelo cliente.

Como lidar, então, com o impasse que se coloca, quando a relação com - paciente e o sigilo ético se confrontam com algo que tem a ver com a saúde da população em geral?

Em princípio, vem-nos uma resposta do próprio Código de Ética da profissão que, em seu artigo 28 , pre-

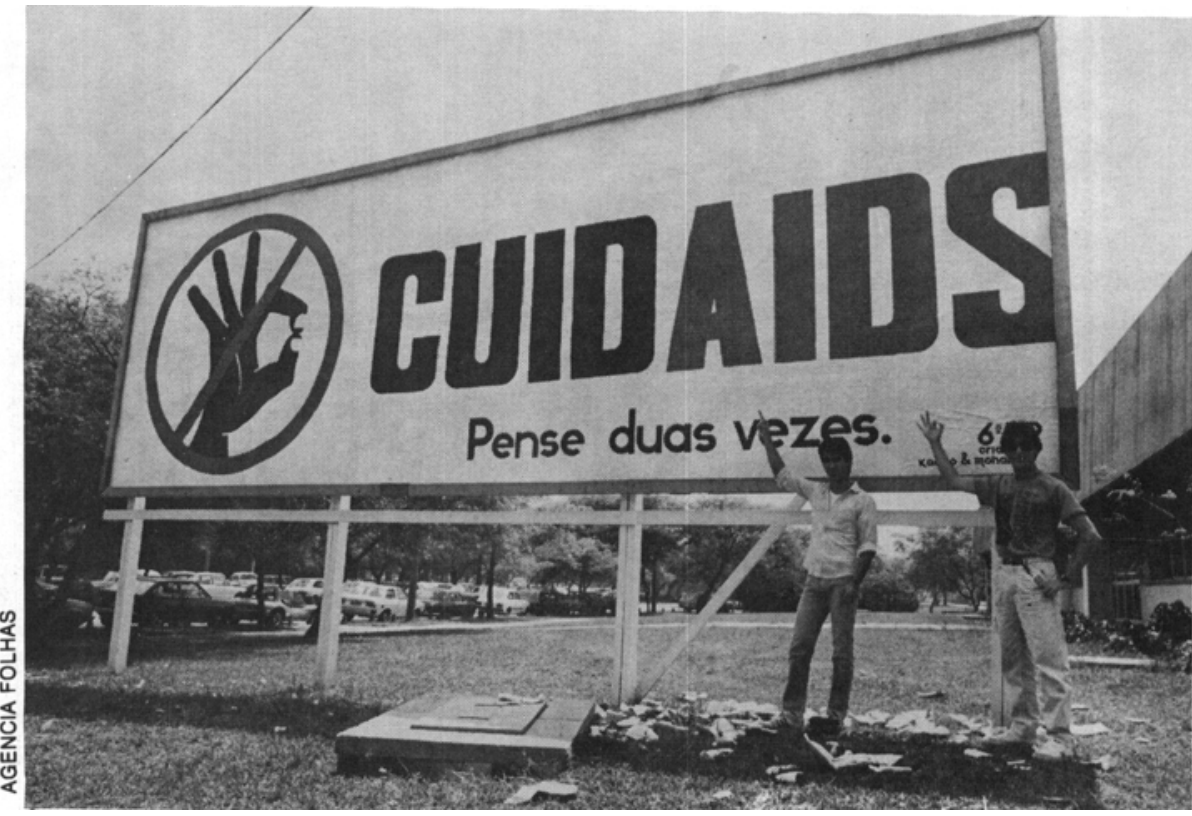

vê: 'A quebra do sigilo só é admissível quando se trata de fato delituoso, previsto em Lei, e a gravidade de suas conseqüências, para o próprio cliente ou para terceiros, possa criar para o Psicólogo o imperativo de consciência de denunciar o fato.'

Se não quiséssemos mais pensar, estaria, aqui, o princípio norteador e justificador da ação profissional nessas ocasiōes: a obrigatoriedade da denúncia. Mas parece que é importante continuar pensándo. $\mathrm{E}$, nesse sentido, não há como fugir da idéia de que, para o psicólogo- para além da relação com o cliente e do significado, em termos de dinấmica intrapsíquica, de uma atitude dessa natureza - colocase o bem-estar e a saúde da população, que, num caso como esse, está, óbvia e perigosamente, em jogo.

Tem sido, portanto, nossa orientação para os psicólogos em situação dessa natureza (e só dessa natureza, porque deve-se tomar o cuidado para não entrar num clima de pânico e preconceito, e denunciar pacientes aidéticos, simplesmente porque são ajdéticos, ou porque falam de suas an- gústias e fantasias, uma vez sabidamente doentes e na iminência de morte real):

10) certificar-se do diagnóstico;

$\left.2^{\circ}\right)$ caso necessário, contatar o médico do cliente, com seu conhecimento sobre o fato;

$\left.3^{\circ}\right)$ avisar o cliente que, até por uma questão ética, ele, o psicólogo, não pode deixar de fazer denúncia de sua conduta (a de deliberadamente criar condições de proliferação da doença);

4) lidar, o máximo possível, com isso, no interior da própria relação com o paciente;

5o) fazer a denúncia ao CRP que, por sua vez, fará o encaminhamento desta ao órgão de saúde competente.

E importante, finalmente, enfatizar que o Conselho está, assim, pronunciando-se publicamente (até porque tem sido solicitado a isso) sobre uma questão muito específica, que, de forma alguma, abrange a totalidade dos pacientes de AIISS, da relação dos psicólogos com esses pacientes, ou das ações da Psicologia em circunstâncias tão adversas de saúde pública." 